Chemotherapy 1995;41(suppl 1):82

\title{
Author Index Vol. 41, Suppl. 1, 1995
}

Carosi, G. 20 Castelli, F. 20 DuPont, H.L. 33 Farthing, M.J.G. 40 Gorbach, S.L. 1 Isolauri, E. 5 Katelaris, P.H. 40 Onnela, T. 5 Rampal, P. 3,48 Salminen, S. 5 Scarpignato, C. 3, 48 Thoren, A. 16

1995;041:82 